\title{
Common low-penetrance risk variants associated with breast cancer in Polish women
}

\author{
Joanna K Ledwoń ${ }^{1}$, Ewa E Hennig ${ }^{1,2^{*}}$, Natalia Maryan¹, Krzysztof Goryca², Dorota Nowakowska³
} Anna Niwińska ${ }^{4}$ and Jerzy Ostrowski ${ }^{1,2}$

\begin{abstract}
Background: Breast cancer is the most common type of cancer and the second leading cause of cancer-death among women in Poland. The known high-risk mutations account for $25 \%$ of familial aggregation cases and $5 \%$ of total breast cancer predisposition. Genome-wide association studies have identified a number of common lowpenetrance genetic variants, but their contribution to disease risk differs between populations.

Methods: To verify selected associations with breast cancer susceptibility among Polish women, the replication study was performed, included 1424 women with breast cancer and 1788 healthy persons. Sixteen singlenucleotide polymorphisms (SNPs) were analyzed using TaqMan SNP Genotyping Assays. Allele frequency differences were tested using chi $^{2}$-test implemented in PLINK v1.07 and Cochran-Armitage trend test was performed using R software.

Results: Significant differences (Bonferroni corrected $p$-value cor $\leq 0.0197$ ) in the frequency of alleles distribution between all cancer and control subjects were observed for four (rs2736098, rs13281615, rs1219648, rs2981582) out of 16 SNPs. The same result was obtained for group of patients without high-risk BRCA1/2 mutations. The rs 1219648 ( $p$-value cor $\leq 6.73 \mathrm{E}-03$ ) and rs2981582 ( $p$-value cor $\leq 6.48 \mathrm{E}-03$ ) SNPs showed significant association with both familial and sporadic cancers. Additionally, rs2736098 ( $p$-value cor $\leq$ 0.0234) was associated with only sporadic cancers; also in group without carriers of high-risk mutation. All these associations revealed their significance also in CochranArmitage trend test. Opposite to other SNPs, rs2736098 was associated with a decreased risk of breast cancer.

Conclusion: The association of four known susceptibility SNPs, representing three individual loci, with breast cancer risk in Polish women was confirmed. One of them (rs2736098) seems to be specific for the Polish population. Due to the population differences in allele frequencies, identification of general genetic risk factors requires sets of association studies conducted on different populations.
\end{abstract}

Keywords: Breast cancer, Cancer susceptibility, Single nucleotide polymorphism, Genetic associations

\section{Background}

Breast cancer is the most commonly occurring cancer among women worldwide [1]. In Poland it accounts for over $20 \%$ of all malignant tumors and is the second most frequent cause of cancer-related death [2]. Although the majority of breast cancer cases are sporadic, a noticeable portion results from highly penetrating inherited mutation in susceptibility genes and family history remains

\footnotetext{
* Correspondence: hennige@coi.waw.pl

'Department of Gastroenterology and Hepatology, Medical Center for

Postgraduate Education, Warsaw, Poland

${ }^{2}$ Department of Genetics, Maria Sklodowska-Curie Memorial Cancer Center and Institute of Oncology, Warsaw, Poland

Full list of author information is available at the end of the article
}

the best predictor of their individual risk [3]. Among known predisposition genes, deleterious mutations in $B R C A 1$ and BRCA2 confer the strongest effect on disease susceptibility and are associated with a lifetime risk of breast cancer of up to $85 \%$ for such mutation carriers $[4,5]$.

Even though the impact of high-risk gene mutations is noticeable, they account for only about $25 \%$ of the familial risk and less than $5 \%$ of total breast cancer predisposition, as their frequencies in general population are very low [6]. It is suggested that remaining risk may result from a combination of multiple common variants, each conferring a small effect on breast cancer risk, with odds 
ratio (OR) usually between 1.2 and 1.5 [7,8]. According to the polygenic model, a large number of low-penetrance variants may have cumulative effect on both the overall risk of disease [9] and an early disease onset [10,11].

A number of common single-nucleotide polymorphisms (SNPs) associated with slightly modified risk of different cancers have been identified through genome-wide association studies (GWAS). By far, at least 22 GWAS were conducted for breast cancer on different populations revealing over 36 susceptibility loci [12]. Fifteen of them were consistently confirmed in other GWAS or large replication studies and meta-analyses [11,13-24].

Conducting analyses on different populations increases the chance for generalization of conclusions and identification of causal variants [25]. For its apparently high level of genetic homogeneity [26,27], the Polish population seems to be relevant for determining risk variants with relatively small, although significant, effect on cancer prevalence. In this study we focus on verification of selected associations with breast cancer risk among Polish women. Eleven SNPs were chosen for replication as commonly reported in different studies. Additional five variants were selected for evaluation based on data provided by Genetic Counseling of Cancer CenterInstitute of Oncology in Warsaw as frequently observed in patients treated in Cancer Center. To our knowledge, by now only two of these SNPs were investigated for association with breast cancer susceptibility in Poland.

\section{Methods}

\section{Studied population}

The study was conducted at the Cancer Center-Institute of Oncology in Warsaw and blood samples were collected between 2003-2010. In total, 3212 women were included: 1424 with newly-diagnosed breast cancer $(992$ of less than 50 years of age at diagnosis) and 1788 healthy individuals. The personal and familial cancer history was acquired by comprehensive interviews for all patients. Cases representing families with at least one breast or ovarian cancer diagnosis in a first- or seconddegree relative were considered as familial breast cancer. Patients with less than 50 years of age at the moment of diagnosis were considered as early-onset cases. The detailed study groups statistics are presented in Table 1.
All patients were tested for selected pathogenic mutations in BRCA1 and BRCA2 chosen as the most frequently occurred among Polish women with breast cancer [26,28]. For $B R C A 1$, the whole sequence of exons 2, 5 and 20, and a part of exon 11 (nucleotides 2893 to 3502 from the beginning of this exon) were analyzed. The sequences of primers used for amplification of relevant fragments are listed in Additional file 1: Table S1. All identified mutations are presented in Table 2; women with at least one of these mutations were further considered as high-risk mutation carriers. For BRCA2, selected 11 mutations (G1408T, 5467insT, 6174delT, 6192delAT, 6675delTA, 8138del5, 9152delT, 9182-2A>G, 9326insA, C9610T, 9631delC) were directly sequenced and none of included patients carried any of these mutations. Healthy women were recruited primarily from the National Colorectal Cancer Screening Program, which enrolls healthy persons from the general population aged 50 years and older. All women exhibited no known history of cancer and normal results of mammography and screening colonoscopy. All patients and control subjects were Polish Caucasians recruited from two urban populations, Warsaw and Szczecin. The study was approved by the local ethics committee (Medical Center for Postgraduate Education and Cancer CenterInstitute of Oncology, Warsaw, Poland) and all participants provided written informed consent. The study protocol conforms to the ethical guidelines of the 1975 Declaration of Helsinki.

\section{SNP selection}

Sixteen SNPs were selected for replication among Polish women (Table 3); 11 SNPs were chosen from the literature as consistently shown to be associated with breast cancer risk in various studies (8 SNPs from GWAS and 3 from candidate gene studies) [8,29-35]. Additional five SNPs were selected based on data provided by Genetic Counseling of Cancer Center-Institute of Oncology in Warsaw, Poland, as relatively frequent among coming forward patients. All five are missense variants in three genes: BRCA2 (3 SNPs), PALB2 and CDKN2A. One of these SNPs (rs1799944 in BRCA2) was previously reported to be associated with breast cancer in Cyprus [36]. For rs3731249 in CDKN2A, contribution to early onset breast cancer in Poland was suggested [37].

Table 1 Group statistics of study cohorts

\begin{tabular}{|c|c|c|c|c|}
\hline & High risk mutation carriers ${ }^{*}$ & No $B R C A 1 / 2$ mutation carriers & Total & Median age \\
\hline Familial BCa (with family history) & 168 & 617 & 785 & $43(29-65)$ \\
\hline Sporadic BCa (without family history) & 75 & 564 & 639 & $45(17-62)$ \\
\hline All BCa cases & 243 & 1181 & 1424 & $44(17-65)$ \\
\hline Controls & - & - & 1788 & $58(26-79)$ \\
\hline
\end{tabular}

${ }^{*}$ Women with any of BRCA1 mutations presented in Table 2. None of patients carried any of selected BRCA2 mutations. 
Table 2 Mutations detected in the selected regions of BRCA1 gene among study participants

\begin{tabular}{cccc}
\hline Exon $\mathbf{2}$ & Exon $\mathbf{5}$ & Exon 11 - part $^{\text {* }}$ & Exon 20 \\
\hline 185delAG & T300G & 3819del5 & G5332A \\
& & 3875del4 & C5370T \\
& 4153delA & 5382insC \\
& 4160delAG & \\
& 4184del4 & \\
\hline
\end{tabular}

"Nucleotides 2893 to 3502 from the beginning of the exon 11 of BRCA1 gene.

Remaining four SNPs have not, so far, been studied for association with breast cancer risk among Polish women.

\section{Genotyping}

Genomic DNA was extracted from whole blood treated with EDTA using the QIAamp DNA mini Kit (Qiagen, Gernamy), following the manufacturer's protocol. DNA samples quantity and quality were evaluated using a NanoDrop 1000 spectrophotometer (Thermo Fisher Scientific Inc., USA). The samples which passed quality control were adjusted to a final concentration of $50 \mathrm{ng} /$ $\mu \mathrm{l}$ in Tris-EDTA buffer $(\mathrm{pH}=8)$, with concentrations of Tris and EDTA not exceeding limits of 10 and $0.1 \mathrm{mM}$, respectively. Individual genotyping was performed using TaqMan SNP Genotyping Assays (Life Technologies, USA), SensiMix ${ }^{\text {Tn }}$ II Probe Kit (Bioline Ltd, United Kingdom) and a 7900HT Real-Time PCR system (Life Technologies, USA) in 384-well format.

\section{Statistical analyses}

Quality control of TaqMan genotyping results included: thresholds for maximum individual missingness for each of the SNPs $<0.05$, maximum genotype missingness for each of the individuals $<0.05$ and the Hardy-Weinberg disequilibrium $<0.001$ for the control group. Associations were examined using allelic $\mathrm{chi}^{2}$-test implemented in PLINK v1.07 software (http://pngu.mgh.harvard.edu/ purcell/plink/). Furthermore, the Cochran-Armitage trend test was performed using $\mathrm{R}$ software (http://www.r-project.org/), "coin" library. OR 95\% confidence interval (CI) was estimated by normal approximation implemented in "epitools" package. The Bonferroni correction was used for multiple comparisons and $p$-value $_{\text {cor }}<0.05$ was considered significant. The study sample size calculations were conducted with tools supported in "pwr" library, assuming equal sizes of groups and baseline allele frequency equal to frequency observed in control group. Calculations were performed for power equal 0.8 and significance threshold equal 0.05 . Results of sample size calculations are presented in Additional file 2: Table S2.

\section{Results}

The vast majority of 1424 women with breast cancer included in this study were non high-risk $B R C A 1$ or BRCA2 mutation carriers: only $243(17.1 \%)$ patients had one of BRCA1 mutations indicated in Table 2 and none of them had any of 11 genotyped mutations in BRCA2. The number of patients with family cancer history was similar to the number of sporadic tumor

Table 3 SNPs selected for analysis

\begin{tabular}{|c|c|c|c|}
\hline NCBI SNP Reference & Cytogenetic Band & Gene $^{a}$ & Reference \\
\hline rs17468277 & $2 q 33.1$ & ALS2CR12 (synonymous) (CASP8) & {$[35]$} \\
\hline rs13387042 & $2 q 35$ & intergenic & {$[32,33]$} \\
\hline rs889312 & $5 q 11.2$ & MAP3K1 (upstream) & {$[8,33]$} \\
\hline rs10941679 & $5 p 12$ & intergenic & {$[8,34]$} \\
\hline rs2736098 & $5 p 15.33$ & TERT (synonymous) & [31] \\
\hline rs13281615 & $8 q 24.21$ & intergenic & {$[8,33]$} \\
\hline rs3731249 & $9 p 21.3$ & CDKN2A (missense; A148T) & {$[37], \mathrm{CO}^{-1}{ }^{c}$} \\
\hline rs1219648 & $10 q 26$ & FGFR2 (intron) & {$[30]$} \\
\hline rs2981582 & $10 q 26$ & FGFR2 (intron) & {$[8,33]$} \\
\hline rs3817198 & $11 p 15.5$ & LSP1 (intron) & {$[8]$} \\
\hline rs766173 & $13 q 13.1$ & BRCA2 (missense; $\mathrm{N} 289 \mathrm{H}$ ) & $\mathrm{CO}-\mathrm{I}$ \\
\hline rs1799944 & $13 q 13.1$ & BRCA2 (missense; N991D) & [36], CO-I \\
\hline rs28897710 & $13 q 13.1$ & BRCA2 (missense; T598A) & CO-I \\
\hline rs3803662 & $16 q 12.1$ & TOX3/LOC643714 (between) & {$[8,32,33]$} \\
\hline rs243865 & $16 q 13-q 21$ & MMP2 (promoter) & [29] \\
\hline rs152451 & $16 p 12.2$ & PALB2 (missense; Q559R) & CO-I \\
\hline
\end{tabular}

a/NCBI ID of genes localized in proximity to the SNPs of interest (source: HapMap).

b/SNP rs17468277 is in strong LD $\left(r^{2}=1\right)$ with rs1045485 in CASP8 (D302H).

c/SNP selected based on the date provided by Genetic Counseling of Cancer Center and Institute of Oncology (CO-I) in Warsaw. 
cases (785 vs. 639), as shown in Table 1 . The median age at diagnosis was 44, ranging from 17 to 85 .

The differences ( $p$-value $\leq 0.0314)$ were observed for seven out of 16 SNPs when allele frequencies between all cases and control subjects were assessed with the chi $^{2}$-test and four of them (rs2736098, rs13281615, rs1219648, rs2981582) remained significantly associated after multiple testing adjustment ( $p$-value cor $\leq 0.0197)$ (Table 4 and Additional file 3: Table S3 for all results). The same four SNPs show significant association $(p$-value cor $\leq$

Table 4 The significant SNP associations with breast cancer considering allelic and Cochran-Armitage trend tests

\begin{tabular}{|c|c|c|c|c|c|c|c|c|c|}
\hline \multirow{2}{*}{$\begin{array}{c}\text { dbSNP } \\
\text { ID }^{a}\end{array}$} & \multirow[t]{2}{*}{ Region } & \multirow[t]{2}{*}{ Gene $^{b}$} & \multirow[t]{2}{*}{ MA } & \multirow[t]{2}{*}{ G1 vs $\mathrm{G} 2$} & \multirow[t]{2}{*}{ OR $(95 \% \mathrm{Cl})$} & \multicolumn{2}{|c|}{ Allelic } & \multicolumn{2}{|c|}{ Cochran-Armitage } \\
\hline & & & & & & $p$-value & $p$-value ${ }_{\text {cor }}$ & $p$-value & $p$-value ${ }_{\text {cor }}$ \\
\hline \multirow[t]{4}{*}{ rs10941679 } & $5 p 12$ & & 0.24 & C vs N & $1.14(1.01-1.28)$ & 2.97E-02 & 4.75E-01 & 2.71E-02 & 4.34E-01 \\
\hline & & & & C noMut vs $\mathrm{N}$ & $1.15(1.02-1.30)$ & 2.29E-02 & $3.66 \mathrm{E}-01$ & 2.04E-02 & 3.27E-01 \\
\hline & & & & S vs N & $1.17(1.01-1.35)$ & 4.25E-02 & $6.80 \mathrm{E}-01$ & $3.94 \mathrm{E}-02$ & $6.31 \mathrm{E}-01$ \\
\hline & & & & S noMut vs $N$ & $1.20(1.03-1.40)$ & 2.06E-02 & $3.29 \mathrm{E}-01$ & 1.87E-02 & 2.99E-01 \\
\hline \multirow[t]{7}{*}{ rs2736098 } & $5 p 15.33$ & TERT & 0.36 & C vs N & $0.77(0.68-0.88)$ & 5.81E-05 & $9.30 \mathrm{E}-04$ & $5.51 \mathrm{E}-05$ & $8.82 \mathrm{E}-04$ \\
\hline & & & & C noMut vs $\mathrm{N}$ & $0.78(0.69-0.89)$ & 2.37E-04 & $3.78 \mathrm{E}-03$ & $2.25 \mathrm{E}-04$ & $3.60 \mathrm{E}-03$ \\
\hline & & & & C with Mut vs N & $0.74(0.57-0.94)$ & 1.70E-02 & $2.73 \mathrm{E}-01$ & $1.55 \mathrm{E}-02$ & $2.48 \mathrm{E}-01$ \\
\hline & & & & F vs $N$ & $0.81(0.69-0.93)$ & 4.68E-03 & 7.49E-02 & 4.56E-03 & 7.30E-02 \\
\hline & & & & F noMut vs $N$ & $0.80(0.68-0.94)$ & 8.63E-03 & $1.38 \mathrm{E}-01$ & $8.25 \mathrm{E}-03$ & $1.32 \mathrm{E}-01$ \\
\hline & & & & S vs $N$ & $0.74(0.63-0.87)$ & 2.61E-04 & 4.17E-03 & 2.38E-04 & $3.80 \mathrm{E}-03$ \\
\hline & & & & S noMut vs N & $0.76(0.64-0.90)$ & $1.46 \mathrm{E}-03$ & $2.34 \mathrm{E}-02$ & $1.36 \mathrm{E}-03$ & $2.18 \mathrm{E}-02$ \\
\hline \multirow[t]{6}{*}{ rs13281615 } & $8 q 24.21$ & & 0.45 & C vs N & 1.19 (1.07-1.32) & $1.23 \mathrm{E}-03$ & $1.97 \mathrm{E}-02$ & $1.17 \mathrm{E}-03$ & $1.88 \mathrm{E}-02$ \\
\hline & & & & C noMut vs $\mathrm{N}$ & $1.21(1.08-1.35)$ & 7.23E-04 & $1.16 \mathrm{E}-02$ & 6.77E-04 & $1.08 \mathrm{E}-02$ \\
\hline & & & & $\mathrm{F}$ vs $\mathrm{N}$ & $1.20(1.06-1.35)$ & 5.19E-03 & 8.31E-02 & 5.24E-03 & 8.39E-02 \\
\hline & & & & F noMut vs $\mathrm{N}$ & $1.22(1.06-1.39)$ & 4.60E-03 & 7.36E-02 & 4.53E-03 & $7.25 \mathrm{E}-02$ \\
\hline & & & & S vs $N$ & $1.18(1.03-1.35)$ & $1.61 \mathrm{E}-02$ & $2.57 \mathrm{E}-01$ & $1.42 \mathrm{E}-02$ & $2.27 \mathrm{E}-01$ \\
\hline & & & & S noMut vs N & $1.20(1.04-1.38)$ & 1.09E-02 & $1.74 \mathrm{E}-01$ & $9.61 \mathrm{E}-03$ & $1.54 \mathrm{E}-01$ \\
\hline \multirow[t]{6}{*}{ rs1219648 } & $10 q 26$ & FGFR2 & 0.41 & C vs N & $1.30(1.17-1.45)$ & $1.01 \mathrm{E}-06$ & $1.62 \mathrm{E}-05$ & $1.13 \mathrm{E}-06$ & $1.81 \mathrm{E}-05$ \\
\hline & & & & C noMut vs $\mathrm{N}$ & $1.36(1.22-1.52)$ & 7.20E-08 & $1.15 \mathrm{E}-06$ & 7.95E-08 & $1.27 \mathrm{E}-06$ \\
\hline & & & & F vs $N$ & $1.26(1.11-1.43)$ & 4.21E-04 & $6.73 \mathrm{E}-03$ & $3.76 \mathrm{E}-04$ & $6.01 \mathrm{E}-03$ \\
\hline & & & & F noMut vs $\mathrm{N}$ & $1.33(1.16-1.53)$ & $4.02 \mathrm{E}-05$ & $6.43 \mathrm{E}-04$ & $3.24 \mathrm{E}-05$ & $5.18 \mathrm{E}-04$ \\
\hline & & & & S vs N & $1.36(1.19-1.56)$ & 7.32E-06 & 1.17E-04 & 8.53E-06 & $1.36 \mathrm{E}-04$ \\
\hline & & & & S noMut vs $N$ & 1.39 (1.20-1.59) & $5.58 \mathrm{E}-06$ & $8.92 \mathrm{E}-05$ & $6.76 \mathrm{E}-06$ & $1.08 \mathrm{E}-04$ \\
\hline \multirow[t]{6}{*}{ rs2981582 } & $10 q 26$ & FGFR2 & 0.41 & C vs N & $1.31(1.17-1.45)$ & $9.10 \mathrm{E}-07$ & $1.46 \mathrm{E}-05$ & 1.17E-06 & $1.88 \mathrm{E}-05$ \\
\hline & & & & C noMut vs $\mathrm{N}$ & $1.35(1.21-1.51)$ & $1.20 \mathrm{E}-07$ & $1.91 \mathrm{E}-06$ & $1.54 \mathrm{E}-07$ & $2.46 \mathrm{E}-06$ \\
\hline & & & & F vs $N$ & $1.26(1.11-1.43)$ & 4.05E-04 & $6.48 \mathrm{E}-03$ & 4.09E-04 & $6.54 \mathrm{E}-03$ \\
\hline & & & & F noMut vs N & $1.32(1.15-1.51)$ & $6.49 \mathrm{E}-05$ & $1.04 \mathrm{E}-03$ & $6.11 \mathrm{E}-05$ & 9.77E-04 \\
\hline & & & & S vs N & $1.37(1.19-1.56)$ & 5.70E-06 & $9.12 \mathrm{E}-05$ & 7.67E-06 & $1.23 \mathrm{E}-04$ \\
\hline & & & & S noMut vs N & $1.38(1.20-1.59)$ & 5.69E-06 & $9.11 \mathrm{E}-05$ & 7.97E-06 & $1.27 \mathrm{E}-04$ \\
\hline \multirow[t]{2}{*}{ rs3817198 } & $11 \mathrm{p} 15.5$ & LSP1 & 0.34 & $\mathrm{~F}$ vs $\mathrm{N}$ & $1.16(1.02-1.32)$ & $2.45 \mathrm{E}-02$ & $3.92 \mathrm{E}-01$ & $2.36 \mathrm{E}-02$ & $3.78 \mathrm{E}-01$ \\
\hline & & & & F noMut vs N & $1.16(1.00-1.33)$ & 4.46E-02 & 7.14E-01 & 4.34E-02 & $6.94 \mathrm{E}-01$ \\
\hline \multirow[t]{4}{*}{ rs3803662 } & $16 q 12.1$ & TOX3 & 0.30 & C vs N & $1.13(1.01-1.27)$ & $3.14 \mathrm{E}-02$ & $5.02 \mathrm{E}-01$ & 3.22E-02 & 5.15E-01 \\
\hline & & & & C noMut vs $\mathrm{N}$ & $1.16(1.03-1.31)$ & $1.30 \mathrm{E}-02$ & $2.08 \mathrm{E}-01$ & $1.35 \mathrm{E}-02$ & $2.16 \mathrm{E}-01$ \\
\hline & & & & F noMut vs N & $1.16(1.00-1.34)$ & 4.45E-02 & 7.11E-01 & 4.53E-02 & 7.25E-01 \\
\hline & & & & $S$ noMut vs $\mathrm{N}$ & $1.16(1.00-1.35)$ & 4.75E-02 & 7.61E-01 & 4.82E-02 & 7.71E-01 \\
\hline
\end{tabular}

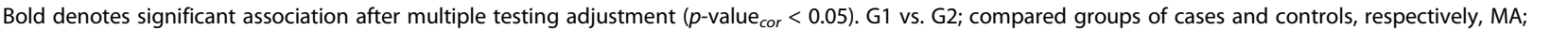
minor allele (+) strand frequency, OR; odds ratio, Cl; confidence interval, N; control, C; cancer (all cases), F; familial cancer, S; sporadic cancer, noMut; non-mutation carriers.

a/SNP identifier based on NCBI SNP database;

${ }^{\mathrm{b}} \mathrm{NCBI}$ ID of genes localized in proximity to the SNPs of interest (source: HapMap). 
0.0116) with breast cancer susceptibility in group of patients tested negative for the high-risk mutations. The strongest association was observed for rs1219648 and rs2981582 ( $p$-value $_{\text {cor }}$ of $1.62 \mathrm{E}-05$ and $1.46 \mathrm{E}-05$, respectively). Both are located in intron 2 of FGFR2 encoding the fibroblast growth factor receptor 2 protein. The minor allele of rs2736098 located in TERT gene was associated

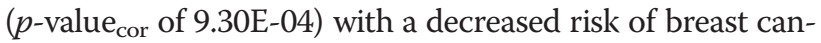
cer. Fourth SNP (rs13281615) was located in 8q24 locus, known as multicancer susceptibility region [38]. None of the 16 SNPs showed association after Bonferroni correction in the group of BRCA1 mutation carriers.

SNPs rs2981582 and rs766173 are in the same linkage disequilibrium (LD) blocks with $\mathrm{rs1219648}\left(r^{2}=0,967\right)$ and rs1799944 $\left(r^{2}=1\right)$, respectively [39]. Consistent with expectations, both pairs indicate similar associations.

To further explore associations with breast cancer, we performed analyses separately in groups of familial and sporadic cases, with additional stratification based on mutations in high-risk genes. Two SNPs in FGFR2 show significant association with both familial and sporadic cases $\left(p\right.$-value $\left._{\text {cor }} \leq 6.73 \mathrm{E}-03\right)$ (Table 4$)$. Additionally, rs2736098 (TERT) was associated with sporadic cancers only $\left(p\right.$-value $\left._{\text {cor }} \leq 0.0234\right)$. Results for both types of breast cancer did not change when carriers of high-risk mutation were excluded. All significant associations obtained in the $\mathrm{chi}^{2}$-test were confirmed by the CochranArmitage trend test analysis (Table 4).

\section{Discussion}

Several association studies support the polygenic inheritance model of breast cancer, showing increasing risk of disease when many predisposition variants of low effect size were combined $[11,40]$. However, strong bias of the association results, by highly penetrant genetic determinants, such as deleterious mutation in BRCA1 or BRCA2 gene, should be taken into account. Also, significant modification of breast cancer risk in BRCA1/2 mutation carriers was observed in association with selected lowpenetrant risk alleles [41].

In this replication study, association of selected susceptibility SNPs with both familial and sporadic breast cancers was analyzed. Among studied patients, at least one from nine different BRCA1 mutations was shown in over $11 \%$ of sporadic cases and $21 \%$ of familial cancers, which is in agreement with previous findings for women in Poland [28].

From 16 susceptibility variants selected for analysis, four SNPs, representing three different loci, significantly associated $\left(p\right.$-value $\left._{\text {cor }}<0.05\right)$ with breast cancer risk, both in group of all cases as in sporadic and familial cancer subgroups, and after exclusion of BRCA1 mutation carriers (Table 4). Two SNPs (rs1219648 and rs2981582) lie within intron 2 of FGFR2 gene, encoding a receptor tyrosine kinase which participates in activation of signaling pathways engaged in tumor induction and progression [42] and mediates breast cancer cell proliferation through D-type cyclins [43]. Amplification or overexpression of FGFR2 was observed in $5-10 \%$ of breast tumors [44] and breast cancer cell lines [45].

The association of FGFR2 variants with breast cancer risk was reported in several studies and is very well documented, with the strongest association observed for rs2981582 [8,30]. Minor allele of rs2981582 was found to correlate with positive family history of breast cancer [46-48] and early-onset of non-familial breast cancer [47]. Data provided by The Consortium of Investigators of Modifiers of BRCA1/2 (CIMBA) indicated that the FGFR2 locus associated with breast cancer in BRCA2 mutation carriers but not in BRCA1 mutation carriers $[49,50]$. This finding may reflect the differences in the distribution of tumor subtype. Rs2981582 is consistently most strongly associated with the estrogen receptor (ER)-positive/low grade tumors [23], which are more typical for BRCA2 mutation carriers and general population not selected for carrier status [51]. Consistently, our findings indicated higher $\mathrm{OR}$ and stronger association of both FGFR2 variants in groups of patients without BRCA1 mutations (Table 4). Possible correlation of FGFR2 risk alleles with gene expression was suggested, as intron 2 contains several putative transcription-factor binding sites [52]. However, relationship of risk allele rs2981582 with increased expression of FGFR2 has not been clarified yet $[52,53]$.

SNP rs13281615 is located in a 'gene desert' on chromosome 8q24, where five independent cancer susceptibility loci were identified so far [54]. One loci, termed 'region 2' (stretched from 128.35-128.51 Mb), is specific for breast cancer only and tagged by rs13281615 [38]. Gene desert at $8 \mathrm{q} 24$ is located few hundred kilo bases telomeric to the proto-oncogene $M y c$. As multiple enhancer elements were identified in this region, it was suggested that they can regulate the transcription of $M y c$. One such element was shown to physically interact with $M y c$ promoter via Tcf-4 transcription factor binding and this interaction affected c-Myc expression in an allele specific manner [55]. Overexpression of c-Myc was observed in breast cancer tissue [56]; its reduction inhibited breast tumor cells growth [57]. In agreement with our findings, SNP rs13281615 was associated with increased risk of breast cancer among people at higher risk (who have positive family cancer history or $B R C A 1 / B R C A 2$ mutation) $[17,48]$. It was also shown that the association of rs13281615 was stronger for ER-positive disease, with no evidence of an association for ER-negative disease [58], although, no association with either $B R C A 1$ or BRCA2 carriers was observed [19]. 
In recent years, the association of rs2736098 (5p15) with cancer risk at different locations was reported, especially for lung and bladder cancers [59-61]. For breast cancer, the reported findings have been controversial [31,60,62]. Haiman et al. [62] observed positive association of $5 \mathrm{p} 15$ locus with increased risk of breast cancer. In turn, Savage et al. [31] suggested protective effect of three correlated SNPs in this region, including rs2736098, among Polish women with positive family history. Similarly, in our study, rs2736098 minor allele was associated with reduced overall and sporadic breast cancer risk. For familial cancers, association was also observed, although not statistically significant after Bonferroni adjustment.

Rs2736098 is located in coding sequence of TERT gene, therefore it has been considered as a putative cancer susceptibility gene. TERT encodes the catalytic subunit of telomerase, which is crucial in cellular proliferation because counteracts telomere-dependent replicative aging [63]. In many types of cancer, TERT shows a high-level of expression, which possibly induces excessive cell growth and carcinogenesis [64]. Although rs2736098 is a synonymous polymorphism, it has been shown to be correlated with telomere length, however not with TERT expression [59]. On the other hand, rs2853669, which is in LD with $\mathrm{rs} 2736098\left(r^{2}=0.79\right)$, was shown to be involved in allele specific regulation of telomerase activity in non-small cell lung cancer [65]. Therefore, rs2736098 might be just a tagging SNP of causal variant.

To our knowledge, this is the first such comprehensive study examining association of several potential lowpenetrance breast cancer susceptibility loci among women in Poland. Beside rs2736098 in TERT, only the association of rs3731249 in CDKN2A was analyzed previously and significant correlation was identified for early-onset breast cancers [37]. Our study do not confirm this association in any of analyzed models. One of possible explanations of this discrepancy is that more invasive and aggressive types of cancers might have been included in previous study. Also, correction of significance for multiple testing was not conducted in that study, comparing with ours. However, lack of this SNP association, similarly like in case of studied $B R C A 1$ variants, could be also explained by insufficient study sample size to detect such association (Additional file 2: Table S2) or SNP effect size lower than expected. The rs2736098 in TERT locus shows protective effect in both studies and it seems to be specific for the Polish women, indicating the benefit of studying small, homogenous populations for low-penetrance risk variants associations.

\section{Conclusions}

We confirmed the association of four SNPs representing three previously reported susceptibility loci with breast cancer risk among Polish women: FGFR2 (rs1219648 and rs2981582), TERT (rs2736098) and 8q24 (rs13281615). Noteworthy is that the minor allele of rs2736098, the synonymous polymorphism in TERT gene, was associated with a decreased risk of overall breast cancer, which by now was observed only among women in Poland. Due to the population differences in allele frequencies, identification of general genetic risk factors requires sets of association studies conducted on different populations. Our study confirmed some benefits of studying small and homogenous populations.

\section{Additional files}

Additional file 1: Table S1. Primers used for amplification of relevant $B R C A 1$ and BRCA2 fragments.

Additional file 2: Table S2. The calculation of sample size necessary for given effect detection with study power equal 0.8 .

Additional file 3: Table S3. SNP associations according to allele frequency test and Cochran-Armitage trend test. Data for all 16 tested SNPS.

\section{Abbreviations}

OR: Odds ratio; SNP: Single-nucleotide polymorphism; GWAS: Genome-wide association studies; Cl: Confidence interval; LD: Linkage disequilibrium; ER: Estrogen receptor.

\section{Competing interests}

The authors declare that they have no competing interests.

\section{Authors' contributions}

Conceived and designed the experiments: JO and EH. Enrolled the patients and performed the experiments: JKL, NM, DN and AN. Analyzed the data: KG, $\mathrm{JKL}$ and $\mathrm{EH}$. Wrote the manuscript: JKL and $\mathrm{EH}$. All authors read and approved the final manuscript.

\section{Acknowledgments}

This work was supported by PBZ-MNiSW-05/I/2007/01 grant from Polish Ministry of Science and Higher Education and 2011/01/B/NZ2/05374 grant from Polish National Center of Science.

\section{Author details}

'Department of Gastroenterology and Hepatology, Medical Center for Postgraduate Education, Warsaw, Poland. 'Department of Genetics, Maria Sklodowska-Curie Memorial Cancer Center and Institute of Oncology, Warsaw, Poland. ${ }^{3}$ Genetic Counseling Unit, Maria Sklodowska-Curie Memorial Cancer Center and Institute of Oncology, Warsaw, Poland. ${ }^{4}$ Department of Breast Cancer and Reconstructive Surgery, Maria Sklodowska-Curie Memorial Cancer Center and Institute of Oncology, Warsaw, Poland.

Received: 26 April 2013 Accepted: 23 October 2013

Published: 30 October 2013

\section{References}

1. Ferlay J, Shin H, Bray F, Forman D, Mathers C, Parkin DM: GLOBOCAN 2008 v1.2, Cancer Incidence and Mortality Worldwide: IARC CancerBase No. 10. http://globocan.iarc.fr/.

2. Wojciechowska U, Didkowska J, Zatonski W: Cancer in Poland in 2008. 2010:1-124. http://onkologia.org.pl/wp-content/uploads/Nowotwory2008.pdf.

3. Foulkes WD: Inherited susceptibility to common cancers. N Engl J Med 2008, 359:2143-2153.

4. Antoniou A, Pharoah PDP, Narod S, Risch HA, Eyfjord JE, Hopper JL, Loman N, Olsson H, Johannsson O, Borg A, Pasini B, Radice P, Manoukian S, Eccles DM, Tang N, Olah E, Anton-Culver H, Warner E, Lubinski J, Gronwald J, Gorski B, Tulinius H, Thorlacius S, Eerola H, Nevanlinna H, Syrjäkoski K, 
Kallioniemi O-P, Thompson D, Evans C, Peto J, et al: Average risks of breast and ovarian cancer associated with BRCA1 or BRCA2 mutations detected in case Series unselected for family history: a combined analysis of 22 studies. Am J Hum Genet 2003, 72:1117-1130.

5. Metcalfe K, Lubinski J, Lynch HT, Ghadirian P, Foulkes WD, Kim-Sing C, Neuhausen S, Tung N, Rosen B, Gronwald J, Ainsworth P, Sweet K, Eisen A, Sun P, Narod SA, The Hereditary Breast Cancer Clinical Study Group: Family history of cancer and cancer risks in women with BRCA1 or BRCA2 mutations. J Nat Cancer Ins 2010, 102:1874-1878.

6. Thompson D, Easton D: The genetic epidemiology of breast cancer genes. J Mammary Gland Biol Neoplasia 2004, 9:221-236.

7. Antoniou AC, Easton DF: Models of genetic susceptibility to breast cancer. Oncogene 2006, 25:5898-5905.

8. Easton DF, Pooley KA, Dunning AM, Pharoah PDP, Thompson D, Ballinger DG, Struewing JP, Morrison J, Field H, Luben R, Wareham N, Ahmed S, Healey CS, Bowman R, Meyer KB, Haiman CA, Kolonel LK, Henderson BE, Le Marchand L, Brennan P, Sangrajrang S, Gaborieau V, Odefrey F, Shen C-Y, Wu P-E, Wang H-C, Eccles D, Evans DG, Peto J, Fletcher $\mathrm{O}$, et al: Genome-wide association study identifies novel breast cancer susceptibility loci. Nature 2007, 447:1087-1093.

9. Pharoah PDP, Antoniou A, Bobrow M, Zimmern RL, Easton DF, Ponder BAJ: Polygenic susceptibility to breast cancer and implications for prevention. Nat Genet 2002, 31:33-36.

10. Dai J, Hu Z, Jiang Y, Shen H, Dong J, Ma H, Shen H: Breast cancer risk assessment with five independent genetic variants and two risk factors in Chinese women. Breast cancer research: BCR 2012, 14:R17.

11. Harlid S, Ivarsson MIL, Butt S, Grzybowska E, Eyfjörd JE, Lenner P, Försti A, Hemminki K, Manjer J, Dillner J, Carlson J: Combined effect of lowpenetrant SNPs on breast cancer risk. Br J Cancer 2012, 106:389-396

12. Hindorff $L$, MacArthur J, Morales J, Junkins HA, Hall PN, Klemm AK Manolio TA: A Catalog of Published Genome-Wide Association Studies. ; A Catalog of Published Genome-Wide Association Studies. www.genome.gov/gwastudies.

13. Peng S, Lü B, Ruan W, Zhu Y, Sheng H, Lai M: Genetic polymorphisms and breast cancer risk: evidence from meta-analyses, pooled analyses, and genome-wide association studies. Breast Cancer Res Treat 2011, 127:309-324.

14. Milne RL, Benítez J, Nevanlinna H, Heikkinen T, Aittomäki K, Blomqvist C, Arias II, Zamora MP, Burwinkel B, Bartram CR, Meindl A, Schmutzler RK, Cox A, Brock I, Elliott G, Reed MWR, Southey MC, Smith L, Spurdle AB, Hopper JL, Couch FJ, Olson JE, Wang X, Fredericksen Z, Schürmann P, Bremer M, Hillemanns P, Dörk T, Devilee P, van Asperen CJ, et al: Risk of estrogen receptor-positive and -negative breast cancer and single-nucleotide polymorphism 2q35-rs13387042. J Natl Cancer Inst 2009, 101:1012-1018.

15. Zhou P, Du L-F, Lv G-Q, Yu X-M, Gu Y-L, Li J-P, Zhang C: Current evidence on the relationship between four polymorphisms in the matrix metalloproteinases (MMP) gene and breast cancer risk: a meta-analysis. Breast Cancer Res Treat 2011, 127:813-818

16. Chen M-B, Li C, Shen W-X, Guo Y-J, Shen W, Lu P-H: Association of a LSP1 gene rs3817198T $>C$ polymorphism with breast cancer risk: evidence from 33,920 cases and 35,671 controls. Mol Biol Rep 2011, 38:4687-4695.

17. Fletcher O, Johnson N, Gibson L, Coupland B, Fraser A, Leonard A, dos Santos Silva I, Ashworth A, Houlston R, Peto J: Association of genetic variants at $8 \mathrm{q} 24$ with breast cancer risk. Cancer Epidemiol Biomarkers Prev 2008, 17:702-705.

18. Mcinerney N, Colleran G, Rowan A, Walther A, Barclay E, Spain S, Jones AM, Tuohy S, Curran C, Miller N, Kerin M, Tomlinson I, Sawyer E: Low penetrance breast cancer predisposition SNPs are site specific. Breast Cancer Res Treat 2009, 117:151-159.

19. Antoniou AC, Sinilnikova OM, McGuffog L, Healey S, Nevanlinna H, Heikkinen T, Simard J, Spurdle AB, Beesley J, Chen X, Neuhausen SL, Ding YC, Couch FJ, Wang X, Fredericksen Z, Peterlongo P, Peissel B, Bonanni B, Viel A, Bernard L, Radice P, Szabo Cl, Foretova L, Zikan M, Claes K, Greene MH, Mai PL, Rennert G, Lejbkowicz F, Andrulis IL, et al: Common variants in LSP1, $2 \mathrm{q} 35$ and $8 \mathrm{q} 24$ and breast cancer risk for BRCA1 and BRCA2 mutation carriers. Hum Mol Genet 2009, 18:4442-4456.

20. Turnbull C, Ahmed S, Morrison J, Pernet D, Renwick A, Maranian M, Seal S, Ghoussaini M, Hines S, Healey CS, Hughes D, Warren-Perry M, Tapper W, Eccles D, Evans DG, Hooning M, Schutte M, van den Ouweland A, Houlston R, Ross G, Langford C, Pharoah PDP, Stratton MR, Dunning AM,
Rahman N, Easton DF: Genome-wide association study identifies five new breast cancer susceptibility loci. Nat Genet 2010, 42:504-507.

21. Li J, Humphreys K, Heikkinen T, Aittomäki K, Blomqvist C, Pharoah PDP, Dunning AM, Ahmed S, Hooning MJ, Martens JWM, Ouweland AMW, Alfredsson L, Palotie A, Peltonen-Palotie L, Irwanto A, Low HQ, Teoh GHK, Thalamuthu A, Easton DF, Nevanlinna H, Liu J, Czene K, Hall P: A combined analysis of genome-wide association studies in breast cancer. Breast Cancer Res Treat 2010, 126:717-727.

22. Fletcher O, Johnson N, Orr N, Hosking FJ, Gibson LJ, Walker K, Zelenika D, Gut I, Heath S, Palles C, Coupland B, Broderick P, Schoemaker M, Jones M, Williamson J, Chilcott-Burns S, Tomczyk K, Simpson G, Jacobs KB, Chanock SJ, Hunter DJ, Tomlinson IP, Swerdlow A, Ashworth A, Ross G, Dos Santos Silva I, Lathrop M, Houlston RS, Peto J: Novel Breast Cancer Susceptibility Locus at 9q31.2: Results of a Genome-Wide Association Study. J Nat Cancer Inst 2011, 103:425-435.

23. Broeks A, Schmidt MK, Sherman ME, Couch FJ, Hopper JL, Dite GS, Apicella C, Smith LD, Hammet F, Southey MC, Veer LJV'T, De GR, Smit VTHBM, Fasching PA, Beckmann MW, Jud S, Ekici AB, Hartmann A, Hein A, Schulz-Wendtland R, Burwinkel B, Marme F, Schneeweiss A, Sinn H-P, Sohn C, Tchatchou S, Bojesen SE, Nordestgaard BG, Flyger H, Ørsted DD, et al: Low penetrance breast cancer susceptibility loci are associated with specific breast tumor subtypes: findings from the Breast Cancer Association Consortium. Hum Mol Genet 2011, 20:3289-3303.

24. Zhang B, Beeghly-Fadiel A, Long J, Zheng W: Genetic variants associated with breast-cancer risk: comprehensive research synopsis, meta-analysis, and epidemiological evidence. Lancet Oncol 2011, 12:477-488.

25. Jostins L, Barrett JC: Genetic risk prediction in complex disease. Hum Mol Genet 2011, 20:R182-R188.

26. Brozek I, Cybulska C, Ratajska M, Piatkowska M, Kluska A, Balabas A, Dabrowska M, Nowakowska D, Niwinska A, Pamula-Pilat J, Tecza K, Pekala W, Rembowska J, Nowicka K, Mosor M, Januszkiewicz-Lewandowska D, Rachtan J, Grzybowska E, Nowak J, Steffen J, Limon J: Prevalence of the most frequent BRCA1 mutations in Polish population. J Appl Genet 2011, 52:325-330.

27. Górski B, Jakubowska A, Huzarski T, Byrski T, Gronwald J, Grzybowska E, Mackiewicz A, Stawicka M, Bebenek M, Sorokin D, Fiszer-Maliszewska $Ł$, Haus O, Janiszewska H, Niepsuj S, Góźdź S, Zaremba L, Posmyk M, Płuzańska M, Kilar E, Czudowska D, Waśko B, Miturski R, Kowalczyk JR, Urbański K, Szwiec M, Koc J, Debniak B, Rozmiarek A, Debniak T, Cybulski C, et al: A high proportion of founder BRCA1 mutations in Polish breast cancer families. Int J Cancer 2004, 110:683-686.

28. Gaj P, Kluska A, Nowakowska D, Bałabas A, Piątkowska M, Dabrowska M, Niwińska A, Ostrowski J: High frequency of BRCA1 founder mutations in Polish women with nonfamilial breast cancer. Fam Cancer 2012, 11:623-628.

29. Beeghly-Fadiel A, Lu W, Long J-R, Shu X, Zheng Y, Cai Q, Gao Y-T, Zheng W: Matrix Metalloproteinase-2 Polymorphisms and Breast Cancer Susceptibility. Cancer Epidemiol Biomarkers Prev 2009, 18:1770-1776.

30. Hunter DJ, Kraft P, Jacobs KB, Cox DG, Yeager M, Hankinson SE, Wacholder S, Wang Z, Welch R, Hutchinson A, Wang J, Yu K, Chatterjee N, Orr N, Willett WC, Colditz GA, Ziegler RG, Berg CD, Buys SS, McCarty CA, Feigelson HS, Calle EE, Thun MJ, Hayes RB, Tucker M, Gerhard DS, Fraumeni JF Jr, Hoover RN, Thomas G, Chanock SJ: A genome-wide association study identifies alleles in FGFR2 associated with risk of sporadic postmenopausal breast cancer. Nat Genet 2007, 39:870-874.

31. Savage SA, Chanock SJ, Lissowska J, Brinton LA, Richesson D, Peplonska B, Bardin-Mikolajczak A, Zatonski W, Szeszenia-Dabrowska N, Garcia-Closas M: Genetic variation in five genes important in telomere biology and risk for breast cancer. Br J Cancer 2007, 97:832-836.

32. Stacey SN, Manolescu A, Sulem P, Rafnar T, Gudmundsson J, Gudjonsson SA, Masson G, Jakobsdottir M, Thorlacius S, Helgason A, Aben KK, Strobbe LJ, Albers-Akkers MT, Swinkels DW, Henderson BE, Kolonel LN, Le Marchand L, Millastre E, Andres R, Godino J, Garcia-Prats MD, Polo E, Tres A, Mouy M, Saemundsdottir J, Backman VM, Gudmundsson L, Kristjansson K, Bergthorsson JT, Kostic J, et al: Common variants on chromosomes 2q35 and $16 q 12$ confer susceptibility to estrogen receptor-positive breast cancer. Nat Genet 2007, 39:865-869.

33. Thomas G, Jacobs KB, Kraft P, Yeager M, Wacholder S, Cox DG, Hankinson SE, Hutchinson A, Wang Z, Yu K, Chatterjee N, Garcia-Closas M, GonzalezBosquet J, Prokunina-Olsson L, Orr N, Willett WC, Colditz GA, Ziegler RG, Berg CD, Buys SS, McCarty CA, Feigelson HS, Calle EE, Thun MJ, Diver R, 
Prentice R, Jackson R, Kooperberg C, Chlebowski R, Lissowska J, et al: A multistage genome-wide association study in breast cancer identifies two new risk alleles at 1p11.2 and 14q24.1 (RAD51L1). Nat Genet 2009, 41:579-584.

34. Stacey SN, Manolescu A, Sulem P, Thorlacius S, Gudjonsson SA, Jonsson GF, Jakobsdottir M, Bergthorsson JT, Gudmundsson J, Aben KK, Strobbe LJ Swinkels DW, van Engelenburg KCA, Henderson BE, Kolonel LN, Le Marchand L, Millastre E, Andres R, Saez B, Lambea J, Godino J, Polo E, Tres A, Picelli S, Rantala J, Margolin S, Jonsson T, Sigurdsson H, Jonsdottir T, Hrafnkelsson J, et al: Common variants on chromosome $5 \mathrm{p} 12$ confer susceptibility to estrogen receptor-positive breast cancer. Nat Genet 2008, 40:703-706

35. Cox A, Dunning AM, Garcia-Closas M, Balasubramanian S, Reed MWR, Pooley KA, Scollen S, Baynes C, Ponder BAJ, Chanock S, Lissowska J, Brinton L, Peplonska B, Southey MC, Hopper JL, McCredie MRE, Giles GG, Fletcher O, Johnson N, dos Santos SI, Gibson L, Bojesen SE, Nordestgaard BG, Axelsson CK, Torres D, Hamann U, Justenhoven C, Brauch H, Chang-Claude J, Kropp S, et al: A common coding variant in CASP8 is associated with breast cancer risk. Nat Genet 2007, 39:352-358.

36. Loizidou MA, Michael T, Neuhausen SL, Newbold RF, Marcou Y, Kakouri E, Daniel M, Papadopoulos P, Malas S, Hadjisavvas A, Kyriacou K: DNA-repair genetic polymorphisms and risk of breast cancer in Cyprus. Breast Cancer Res Treat 2008, 115:623-627.

37. Debniak T, Górski B, Huzarski T, Byrski T, Cybulski C, Mackiewicz A, Gozdecka-Grodecka S, Gronwald J, Kowalska E, Haus O, Grzybowska E, Stawicka M, Swiec M, Urbański K, Niepsuj S, Waśko B, Góźdź S, Wandzel P, Szczylik C, Surdyka D, Rozmiarek A, Zambrano O, Posmyk M, Narod SA, Lubinski J: A common variant of CDKN2A (p16) predisposes to breast cancer. J Med Genet 2005, 42:763-765.

38. Ghoussaini M, Song H, Koessler T, Al Olama AA, Kote-Jarai Z, Driver KE, Pooley KA, Ramus SJ, Kjaer SK, Hogdall E, DiCioccio RA, Whittemore AS, Gayther SA, Giles GG, Guy M, Edwards SM, Morrison J, Donovan JL, Hamdy FC, Dearnaley DP, Ardern-Jones AT, Hall AL, O'Brien LT, Gehr-Swain BN, Wilkinson RA, Brown PM, Hopper JL, Neal DE, Pharoah PDP, Ponder BAJ, et al: Multiple loci with different cancer specificities within the 8q24 gene desert. J Natl Cancer Inst 2008, 100:962-966.

39. Johnson AD, Handsaker RE, Pulit S, Nizzari MM, O'Donnell CJ, de Bakker PIW: SNAP: A web-based tool for identification and annotation of proxy SNPS using HapMap. Bioinformatics 2008, 24(24):2938-2939.

40. Pharoah PDP, Antoniou AC, Easton DF, Ponder BAJ: Polygenes, risk prediction, and targeted prevention of breast cancer. N Engl J Med 2008, 358:2796-2803.

41. Milne RL, Antoniou AC: Genetic modifiers of cancer risk for BRCA1 and BRCA2 mutation carriers. Ann Oncol 2011, 22(Suppl 1):i11-i17.

42. Eswarakumar VP, Lax I, Schlessinger J: Cellular signaling by fibroblast growth factor receptors. Cytokine Growth Factor Rev 2005, 16:139-149.

43. Koziczak M, Holbro T, Hynes NE: Blocking of FGFR signaling inhibits breast cancer cell proliferation through downregulation of D-type cyclins. Oncogene 2004, 23:3501-3508.

44. Adnane J, Gaudray P, Dionne CA, Crumley G, Jaye M, Schlessinger J, Jeanteur $P$, Birnbaum D, Theillet C: BEK and FLG, two receptors to members of the FGF family, are amplified in subsets of human breast cancers. Oncogene 1991, 6:659-663.

45. Tannheimer SL, Rehemtulla A, Ethier SP: Characterization of fibroblast growth factor receptor 2 overexpression in the human breast cancer cell line SUM-52PE. Breast Cancer Res 2000, 2:311-320.

46. Huijts PEA, Vreeswijk MPG, Kroeze-Jansema KHG, Jacobi CE, Seynaeve C, Krol-Warmerdam EMM, Wijers-Koster PM, Blom JC, Pooley KA, Klijn JGM, Tollenaar RAEM, Devilee P, van Asperen CJ: Clinical correlates of low-risk variants in FGFR2, TNRC9, MAP3K1, LSP1 and 8q24 in a Dutch cohort of incident breast cancer cases. Breast Cancer Res 2007, 9:R78.

47. Jara L, Gonzalez-Hormazabal P, Cerceño K, Di Capua GA, Reyes JM, Blanco R, Bravo T, Peralta O, Gomez F, Waugh E, Margarit S, Ibañez G, Romero C, Pakomio J, Roizen G: Genetic variants in FGFR2 and MAP3K1 are associated with the risk of familial and early-onset breast cancer in a South-American population. Breast Cancer Res Treat 2013, 137:559-569.

48. Latif A, Hadfield KD, Roberts SA, Shenton A, Lalloo F, Black GCM, Howell A, Evans DG, Newman WG: Breast cancer susceptibility variants alter risks in familial disease. J Med Genet 2010, 47:126-131.

49. Antoniou AC, Beesley J, McGuffog L, Sinilnikova OM, Healey S, Neuhausen SL, Ding YC, Rebbeck TR, Weitzel JN, Lynch HT, Isaacs C, Ganz PA, Tomlinson G,
Olopade OI, Couch FJ, Wang X, Lindor NM, Pankratz VS, Radice P, Manoukian S, Peissel B, Zaffaroni D, Barile M, Viel A, Allavena A, Dall'Olio V, Peterlongo P, Szabo Cl, Zikan M, Claes K, et al: Common breast cancer susceptibility alleles and the risk of breast cancer for BRCA1 and BRCA2 mutation carriers: implications for risk prediction. Cancer Res 2010, 70:9742-9754

50. Antoniou AC, Spurdle AB, Sinilnikova OM, Healey S, Pooley KA, Schmutzler RK, Versmold B, Engel C, Meindl A, Arnold N, Hofmann W, Sutter C, Niederacher D, Deissler H, Caldes T, Kämpjärvi K, Nevanlinna H, Simard J, Beesley J, Chen X, Neuhausen SL, Rebbeck TR, Wagner T, Lynch HT, Isaacs C, Weitzel J, Ganz PA, Daly MB, Tomlinson G, Olopade OI, et al: Common breast cancer-predisposition alleles are associated with breast cancer risk in BRCA1 and BRCA2 mutation carriers. Am J Hum Genet 2008, 82:937-948.

51. Lakhani SR, Van De Vijver MJ, Jacquemier J, Anderson TJ, Osin PP McGuffog L, Easton DF: The pathology of familial breast cancer: predictive value of immunohistochemical markers estrogen receptor, progesterone receptor, HER-2, and p53 in patients with mutations in BRCA1 and BRCA2. J Clin Oncol 2002, 20:2310-2318.

52. Meyer KB, Maia A-T, O'Reilly M, Teschendorff AE, Chin S-F, Caldas C, Ponder BAJ: Allele-specific up-regulation of FGFR2 increases susceptibility to breast cancer. PLOS Biol 2008, 6:e108.

53. Sun C, Olopade Ol, Di Rienzo A: rs2981582 is associated with FGFR2 expression in normal breast. Cancer Genet Cytogenet 2010, 197:193-194.

54. Al Olama AA, Kote-Jarai Z, Giles GG, Guy M, Morrison J, Severi G, Leongamornlert DA, Tymrakiewicz M, Jhavar S, Saunders E, Hopper JL, Southey MC, Muir KR, English DR, Dearnaley DP, Ardern-Jones AT, Hall AL, O'Brien LT, Wilkinson RA, Sawyer E, Lophatananon A, Horwich A, Huddart RA, Khoo VS, Parker CC, Woodhouse CJ, Thompson A, Christmas T, Ogden C, Cooper C, et al: Multiple loci on 8q24 associated with prostate cancer susceptibility. Nat Genet 2009, 41:1058-1060.

55. Sotelo J, Esposito D, Duhagon MA, Banfield K, Mehalko J, Liao H, Stephens RM, Harris TJR, Munroe DJ, Wu X: Long-range enhancers on $8 q 24$ regulate c-Myc. Proc Natl Acad Sci U S A 2010, 107:3001-3005.

56. Liao DJ, Dickson RB: c-Myc in breast cancer. Endocr Relat Cancer 2000, 7:143-164.

57. Wang Y, Liu S, Zhang G, Zhou C, Zhu H, Zhou X, Quan L, Bai J, Xu N Knockdown of c-Myc expression by RNAi inhibits MCF-7 breast tumor cells growth in vitro and in vivo. Breast Cancer Res 2005, 7:R220-R228.

58. Garcia-Closas M, Hall P, Nevanlinna H, Pooley K, Morrison J, Richesson DA, Bojesen SE, Nordestgaard BG, Axelsson CK, Arias Jl, Milne RL, Ribas G, González-Neira A, Benítez J, Zamora P, Brauch H, Justenhoven C, Hamann U, Ko Y-D, Bruening T, Haas S, Dörk T, Schürmann P, Hillemanns $P$, Bogdanova N, Bremer M, Karstens JH, Fagerholm R, Aaltonen K, Aittomäki K, et al: Heterogeneity of breast cancer associations with five susceptibility loci by clinical and pathological characteristics. PLOS Genet 2008, 4:e1000054.

59. Rafnar T, Sulem P, Stacey SN, Geller F, Gudmundsson J, Sigurdsson A, Jakobsdottir M, Helgadottir H, Thorlacius S, Aben KKH, Blöndal T, Thorgeirsson TE, Thorleifsson G, Kristjansson K, Thorisdottir K, Ragnarsson R, Sigurgeirsson B, Skuladottir H, Gudbjartsson T, Isaksson HJ, Einarsson GV, Benediktsdottir KR, Agnarsson BA, Olafsson K, Salvarsdottir A, Bjarnason H, Asgeirsdottir M, Kristinsson KT, Matthiasdottir S, Sveinsdottir SG, et al: Sequence variants at the TERT-CLPTM1L locus associate with many cancer types. Nat Genet 2009, 41:221-227.

60. Mocellin S, Verdi D, Pooley KA, Landi MT, Egan KM, Baird DM, Prescott J, De Vivo I, Nitti D: Telomerase reverse transcriptase locus polymorphisms and cancer risk: a field synopsis and meta-analysis. J Nat Cancer Inst 2012, 104:840-854.

61. Zhang X-J, Xu Z, Gong Y-L, Tang C-J, Chen J-F: Association of TERT rs2736098 polymorphism with cancer risk: a meta-analysis. Asian PaC J Cancer Prev 2012, 13:4943-4946.

62. Haiman CA, Chen GK, Vachon CM, Canzian F, Dunning A, Millikan RC, Wang X, Ademuyiwa F, Ahmed S, Ambrosone CB, Baglietto L, Balleine R, Bandera EV, Beckmann MW, Berg CD, Bernstein L, Blomqvist C, Blot WJ, Brauch H, Buring JE, Carey LA, Carpenter JE, Chang-Claude J, Chanock SJ, Chasman DI, Clarke CL, Cox A, Cross SS, Deming SL, Diasio RB, et al: A common variant at the TERT-CLPTM1L locus is associated with estrogen receptor-negative breast cancer. Nat Genet 2011, 43:1210-1214.

63. Blackburn EH: Switching and signaling at the telomere. Cell 2001, 106:661-673. 
64. Liu Z, Li G, Wei S, Niu J, Wang L-E, Sturgis EM, Wei Q: Genetic variations in TERT-CLPTM1L genes and risk of squamous cell carcinoma of the head and neck. Carcinogenesis 2010, 31:1977-1981.

65. Hsu C-P, Hsu N-Y, Lee L-W, Ko J-L: Ets2 binding site single nucleotide polymorphism at the hTERT gene promoter-effect on telomerase expression and telomere length maintenance in non-small cell lung cancer. Eur J Cancer 2006, 42:1466-1474.

doi:10.1186/1471-2407-13-510

Cite this article as: Ledwoń et al:: Common low-penetrance risk variants associated with breast cancer in Polish women. BMC Cancer 2013 13:510.

\section{Submit your next manuscript to BioMed Central and take full advantage of:}

- Convenient online submission

- Thorough peer review

- No space constraints or color figure charges

- Immediate publication on acceptance

- Inclusion in PubMed, CAS, Scopus and Google Scholar

- Research which is freely available for redistribution 